\title{
Omnichannelling and the Predominance of Big Retailers in the post-Covid Era*
}

\author{
Fabio Fortuna ${ }^{* *}$, Mario Risso ${ }^{* * *}$, Fabio Musso ${ }^{* * * * *}$
}

\begin{abstract}
The Covid 19 pandemic has profoundly affected the competitive context of retail companies. Multiple changes have occurred both in consumer behaviour, in retail strategy and marketing channels. In particular, the pandemic has accelerated the use of digital technology in the processes of physical purchase and distribution of retail products, favouring new forms of integration between physical and online channels (so-called omnichannelling).

Many brick\&mortar stores have closed down, others have modified their original logistic functions in favor of the new digital integrated ones, with a smaller number of point of sales assuming the connotation of flagship stores with greater force. Some cases confirm the acceleration that took place towards the integration and redefinition of the roles of physical and online channels. The biggest retailers empower their predominance in the global markets. Smaller operators could renew their role by shaping new forms of collaboration to survive.
\end{abstract}

Keywords: Omnichannel; COVID19; Digital Transformation; Physical and Online Stores; Inditex; Zara; Supply Chain; Consumer Behaviour; Retail; Global Markets

\section{Marketing Channels and Pre-Covid Trends}

The Covid-19 pandemic, which occurred in the first half of 2020, had strong consequences both at the economic level, with the interruption of production activities, and at the social level, as it strongly impacted on people's daily lives, whereby habits and behaviors underwent a sudden change that was difficult to predict. This occurred in a historical period in which technological innovations were already producing significant changes as regards production and exchange processes, which have been accelerated. Thus, it can be assumed that what has changed in a few months, especially in the relationship between producers of goods and services, intermediate demand (distributors and retailers) and final demand was not only due to the Covid-related context. Rather, these changes should be read as definitive

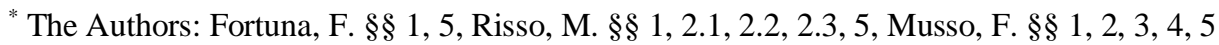

**Full Professor of Business Administration, Niccolò Cusano University (fabio.fortuna@ unicusano.it)

*** Full Professor of Business Management, Niccolò Cusano University (mario.risso@unicusano.it)

${ }^{* * * *}$ Full Professor of Business Management, Carlo Bo University of Urbino (fabio.musso@ uniurb.it)
}

Edited by: Niccolò Cusano University

ISSN: 1593-0319

Fortuna, F., Risso, M., \& Musso, F. (2021). Omnichannelling and the Predominance of Big Retailers in the Post-Covid Era. Symphonya. Emerging Issues in Management (symphonya.unicusano.it), (2), $142-157$

https://dx.doi.org/10.4468/2021.2.11fortuna.risso.musso 
modifications whose direction can indicate further paths of evolution that will occur within a few years.

The digitalization of processes has led companies, on the one hand, to adapt to new market contexts, and on the other to integrate traditional communication and sales channels with new digital channels (Premnath, 2021; Moses \& Clark, 2020; Musso, 2012; Musso \& Adam, 2020).

For example, the retail sector is rapidly moving from a well-established approach of multi-channelling to an emerging one of omnichannel retailing, i.e. an evolution of the multi-channel approach in which the various channels are integrated with each other and the experience of the consumer can take place without interruption from one channel to another. And, it is in the retail sector that the combination of technological innovation, associated with communication technologies, and changes in consumer behavior, bear the impact on economic and social relations.

This paper aims to explore the impact of the COVID-19 pandemic on the retail sector, identifying the evolution patterns from multichanneling to omnichanneling. Future possible post COVID trends for large and small retailers are identified. The analysis is based on a literature review using the Scopus database and some other relevant sources. Using "Scopus", the research was based on keywords "Retail" and "COVID-19" and limited to Business, Management and Accounting section. Out of the 126 articles reviewed, 58 were removed because they were not related to the objective of this paper. 68 articles were selected to inform the analysis and the discussion of the results. Table n. 1 shows the three key issues of academic studies which were identified.

Table 1: The Issues of Academic Studies in Retail and COVID 19

\begin{tabular}{|l|c|}
\hline Issues & No. of documents \\
\hline Changes in Consumer behaviour & 24 \\
\hline Retail marketing strategies & 31 \\
\hline The importance of retail supply chain & 12 \\
\hline
\end{tabular}

\section{Analyzing the Impact of the COVID-19 Pandemic on the Retail Sector}

Before the pandemic, the rapid development of digital technologies and the search for innovative solutions in the production of goods / services and their distribution, spurred change in the way in which consumers use products and services (Bacile et al., 2014). Services have become a fundamental tool for adding value to products. Technological development, as the main driver of innovation in the modern economy, has increased the demand for innovations in services, so that even companies whose production was basically traditional, are changing their approach, opening room for more services in their product offer (Pantano et al., 2018). This has forced a change in marketing activities, that have shifted their focus by highlighting the role of the consumer as a co-producer of the service itself (Chathoth et al., 2013). It is therefore worth investigating the impact of the pandemic on marketing activities, on consumer behavior, as well as on the supply chain/channel perspective. 


\subsection{Changes in Retail Consumer Behavior}

COVID-19 and quarantine have influenced the consumer behavior both negatively and positively (Tanveer et al, 2020). Many studies have modelled the change in shopping behavior for retail products before and after the pandemic (Pratiwi et al, 2021; Jiang \& Stylos, 2021). Psychological factors such as uncertainty, perceptions of severity, perceptions of scarcity, and anxiety have resulted in consumer panic purchasing behavior (Omar et al, 2021).

Hall et al. (2021) provide evidence of spatial and temporal displacement of consumption based on consumer spending patterns.

Consumers now have higher expectations for in-store safety, hygiene practices and empathy; they have reduced the frequency of store patronage, travel time, and instorepresence; they have shifted away from regular shopping habits and destinations; and they have spent more across various types of online grocery shopping platforms. (Wang et al, 2020; Yang et al., 2021; Itani \& Hollebeek, 2021).

Consumers use e-commerce to react to, cope with and adapt to periods of restrictions of freedom of movement (Guthrie et al, 2021). The pandemic has acted as a catalyst for integrating e-commerce into the retail ecosystem, especially during lockdowns (Beckers et al, 2021).

E-commerce retail entities operating in countries where the mall culture is prevalentshould formulate their strategy to accommodate the shopping preferences of both online and in-store customers (John \& Dani, 2021).

During the COVID-19 pandemic, perceived health risk as well as security, privacy, reliability fulfillment, and service recovery affected online shopping behavior (Fihartini et al, 2021). The protective measures adopted by retailers against the COVID-19 virus significantly and positively influenced customer safety during shopping, their attitudes and satisfaction, which resulted in an increase of their behavioral intentions towards new integrated forms of digital and face-to-face shopping (Untaru \& Han, 2021; Kazancoglu \& Demir, 2021). Retailers are expected to re-design their business settings and adopt protective and preventive measures to encourage visitation of their stores (Filimonau et al, 2021), to improve customer satisfaction towards web stores (Mofokeng, 2021; Thaipradit \& Tantong, 2021).

In fact, in the aftermaths of the pandemic, consumers are more inclined to shop on omnichannel if they believe the benefits outweigh the risks (Chatterjee et al, 2021).

\subsection{The Impact of COVID 19 on Retail Marketing Activity}

Pantano et al. (2020) synthesize the challenges that retailers are facing during the COVID-19 emergency, from the perspective of both consumers and managers.

Technology is changing retail (Siriwardhana et al, 2020) and affects shoppers, retailers, employees, and suppliers (Shankar et al, 2021)

Digital customer experience is important and it can be used to create a competitive advantage, to evaluate the various challenges for traditional retail businesses that undertake a digital transformation strategy (Schoeman et al, 2021).

In advanced retail market, large retailers are dynamic and adapt their marketing strategies to the changes in consumer behavior with multiple players and formats (Pradhan \& Bhatkal, 2021).

The interplay between capacity, pricing, and online retailing mode are affected by 
the absence/presence of the pandemic. A new equilibrium between the Brick \& Mortar retailer and the Online-to-offline $(\mathrm{O} 2 \mathrm{O})$ platform provider is necessary $(\mathrm{He}$ et al, 2021). Grewal et al. (2021) highlighted a strategic Wheel of Retailing in the new technology era. Technology is the core enabler of the strategies related to the 6 Ps of retailing (retail place and supply chain management, product, pricing, promotion, personnel, and presentation) and to maintain the service capacity of sustainable operations in retail stores (Milman et al, 2020; Zhou, 2020; Chang, 2021; Gupta et al, 2021; Jafarzadeh et al, 2021).

Online shopping by mass consumers has increased significantly during the pandemic (Showrav et al, 2021) and retailers should develop strategies to protect them and understand that the use of technology will become the new normal (Khaled et al, 2020; Northington et al, 2021; Park et al, 2021). Digital and social media marketing strategies, including campaign development, implementation, measurement and results and an immersive in-store experience offered to customers could increase purchases within physical store locations when social distancing directives for COVID-19 are fully lifted and business returns to normal (Smith, 2020). Therefore, retailers should develop new strategies and plans to increase sales volume and create strong relationships with online customers by providing trustworthiness and security in buying practices (Lavuri, 2021).

The omni-channel strategy seems suitable to respond to the challenging retail landscape (Zhang et al, 2021). In fact, in the post Covid world, Brick \& Mortar retailing will not only survive but also thrive by repositioning from selling merchandise to offering value-added services and from a low-tech to high-tech experience in the store (Sheth, 2021).).

\subsection{The Pivotal Role of the Retail Supply Chain}

Some studies show the importance of supply chain management especially in retail supply chains during the pandemic. Love et al (2021) highlight how the reality of COVID-19 is affecting producer establishments differently, depending on many factors including their market channel (Bretas \& Alon, 2020). Many large retailers are designing/redesigning a resilient retail supply chain network under uncertainty (Alikhani et al, 2021). The adoption of lean manufacturing/agile philosophy in retail business will have a huge positive impact on customers' satisfaction and may lead to minimize the negative impact of COVID 19 (Mefi \& Asoba, 2020; Abdelhadi, 2021). A "Collaboration Efficiency" is a main criterion for accelerating the performance of retail supply chains in a dynamic digital social environment (Sharma et al., 2021). Traceability system; the adoption of electronic data exchange (EDI), radio frequency identification (RFID), and blockchain are amongst the most significant tools with a positive impact on the performance in retail supply chains during and after the Covid19 pandemic (Sathyanarayana et al, 2020; Masudin et al, 2021; Burgos \& Ivanov, 2021).

The optimization of resources to overcome the negative impacts of the pandemic and improve retailers' competitiveness require important investments with a structured approach upstream, internal and operational, and downstream and with respect to customer perspectives.

While some large retailers as Marks and Spencer have implemented ad hoc solutions (Schleper et al., 2021) all retailers that want to strengthen and improve 
resilience are called to reshape their supply chains to respond to the meets of emerging consumer behavior. (Montoya \& Flores, 2021; Su et al, 2021; Cole \& Shirgholami, 2021).

\section{From Multichanneling to Omnichanneling}

Such a new vision has led to changes also in marketing channels, for which both producers and retailers have been stimulated to develop ad hoc abilities to integrate their traditional knowledge and skills with those emerging from the interaction with consumers. (Ngo \& O'Cass, 2013). Among the major changes that have occurred, there are three that have resulted in greater impact: proximity marketing, self-service technologies and augmented reality.

Proximity marketing is a consequence of the diffusion of smartphones, which favored the development of location-based services, which exploit the integration within the smartphone of technologies for the detection of the geographical position (Global Positioning System - GPS) or the proximity of an information exchange device (Farrelly, 2012).

Proximity marketing is defined as an emerging marketing method based on realtime mobility and geolocation of consumers, through wireless and interactive technologies (Wi-Fi, Bluetooth, Near Field Communication etc.). In addition to interaction, another typical feature of proximity marketing is the personalization and sending of content at specific times and places: it is therefore defined as a marketing service that allows creating and sending to specific targets personalized and contextualized contents directly on the smartphone equipped with a special app (Levesque \& Boeck, 2017; Willems et al., 2017).

It is thanks to the combination of these technologies with other tools and formats (such as apps, push notification, mobile advertising, etc.) that it is possible to develop proximity marketing strategies (Dmitry, 2013; Namiot \& Sneps-Sneppe, 2013).

From a consumer perspective, this technology is used to fuel and leverage word of mouth, by writing/consulting reviews of shops, restaurants and other businesses via mobile applications, and this allows for a consumer-powered connection between retailer and consumer (McCormick et al., 2014).

With reference to the second point - self-service technologies - they are stimulated by companies because they help in reducing operating costs when providing the service. However, consumers show a growing interest in pleasant experiences at the point of sale and not always they derive a positive perception from the use of these technologies. Therefore, their impact on the quality of the service must be compared with that of the service provided by the store staff (Demirkan \& Spohrer, 2014). Their effectiveness may better emerge in more traditional retail environments, where consumers often feel discouraged in terms of inadequate services, such as long waiting times at the checkout or for staff assistance. To this end, new technologies have started to be experimented within the points of sale, as in the case of Amazon Go stores (Polacco Backes, 2018; Ives et al., 2019) or in the context of fashion retail, with the adoption of smart mirrors (Luce, 2019), which allow a dress to be overlayed on the customer's reflected image, thus allowing him to try on various garments without having to physically wear them and without the assistance of the sales staff.

The example of smart mirrors recalls the third key change, that is, augmented 
reality. Augmented reality is defined as "a technology that allows to combine reality and digital information generated by a computer within the user's field of view so that they appear as a single environment" (Olsson et al., 2013, p. 288). The applications can involve the use of smartphones or the creation of digital kiosks that can perform various functions: in addition to being a simple mirror, digital kiosks can also act as a multimedia totem to view the catalog of available products or as digital signage, or can be used for self-checkout for the payment of the purchased products. In addition, with QR code technology, offline communications can be integrated with online communications.

As seen so far, recent technological advances in mobile devices and augmented reality are reducing the difference between producer-consumer interactions and retailer-consumer interactions. In both cases, the mix of offline sensory information and online content makes an increasingly complex integration between marketing channels (Brynjolfsson et al., 2013). These advances have led to the growth of omnichannel retailing as an evolution of the multichannel approach.

With multichanneling, the consumer has the opportunity to carry out the purchase process both through online channels (computer or smartphone), and through offline channels (physical store). This involves numerous challenges, identified by Rosenbloom (2007) in the following: creating synergies between channels, building strategic alliances, finding the optimal channel mix, creating a sustainable competitive advantage. Moreover, multichannelling increases the complexity of consumer behavior, making more complex pricing and brand strategies.

The potential of multi-channel strategy is expressed through six dimensions of integration (Oh et al., 2012): advertising, sharing of information on online and offline transactions between the various channels, consistency of information on prices and products between channels, interchannel access to information, possibility for the consumer to define the channel of delivery or collection of the product and payment, access to customer service whatever the chosen channel.

An evolution of the integrated multichannel concept is represented by omnichanneling, which is currently one of the most important drivers of the evolution of relationships between consumers, on the one hand, and producers and retailers on the other. Omnichannel retailing consists of an advanced integration between the various channels that allows the consumer to have a seamless experience despite the use of various channels and devices to access them. McCormick et al. (2014) list the main elements that characterize this approach, which are:

- Simultaneous use of channels by consumers for shopping, especially among younger groups;

- Consumer connectivity, which exploits various retail channels through digital means, taking over the shopping experience;

- Unified vision of the customer by companies, which exploit various channels through a high degree of sharing of data on customers and the way they interact with companies;

- Continuity between the customer experience in the retail environment and the interaction developed with the manufacturers' brands;

- Consistency which becomes essential to avoid that an inadequate experience in one channel is also projected on the other channels since the consumer is not afraid of changing brands or retailers. 
This new type of structure involves the breaking of old barriers such as geographical ones or those linked to the reduced capacity for comparison of consumers (consequence of information asymmetries), thus entailing a radical change in planning communication and commercial strategies for both producers and retailers, who will tend to have greater attention to content, attractive prices because they are subject to constant comparison, exploitation of data and profiling power (data from social, mobile and even physical channels), diversification of products and brands, niche specializations combined with bundling policies (construction of customized packages of products / services), emphasis on product knowledge accumulated by the consumer in the various interaction (Brynjolfsson et al., 2013).

Consequently, the boundary between manufacturers and retailers becomes thinner with the increase in collaborations between the two parties, up to possible integrations upstream by the retailer or, vice versa, downstream by the manufacturer. The supply chains that generate greater value for the consumer are destined emerge in the long run and the greater degree of transparency, in addition to speeding up this process, also produces a "winner takes all" effect, for which retailers and producers must find the area where they better can take an advantage truly the best. In this context, services become a fundamental ground for guaranteeing the customer a high level of satisfaction with the shopping experience.

\section{The Channels to Come: Post-Covid Trends}

The most substantial impact of the Covid-related emergency was the sharp acceleration on the changing processes that were underway, with a shift to multichannel and omnichannel strategies. However, the road traced is pushing towards further changes, the main features of which are outlined below.

The first change concerns the e-commerce trend. Medium-term forecasts point out an upward trend of e-commerce, but with decreasing annual growth rates (Fig. 1). This may mean that online sales will become more relevant, but this will not lead to a picture of total disintermediation. In any case, the online presence is already pushing some retailers to shift their focus on e-commerce, by closing a number of physical stores. What will remain of brick and mortar retailing will be flagship stores or stores enriched with services and, depending on the assortments, capable of allowing the co-production of products / services or participation in experiences of a mainly social nature. Offline purchases will tend to prefer neighborhood stores and local / national brand products (Accenture, 2020).

$\square$ Inditex group declares its intention to close 1,200 Zara stores, mainly in Asia and Europe. These are the smallest stores, while energy and investment will be focused on iconic flagship stores that have an integrated online-offline concept. Investment in $e$ commerce is a priority for the future based on a hybrid model that marries bricks and mortar and mobile apps. In effect, in October 2020, Inditex opened in Beijing, the first Zara store that deeply embraces the new omnichannel development project of the group. The store as a shop window uses various technologies to offer the consumer a fully integrated experience including mini-distribution 
hubs which support online purchase with the preparation and fulfillment of online orders (Dombey, 2021).

Figure 1: Retail E-commerce Sales Worldwide from 2014 to 2024 (in billion U.S. dollars)

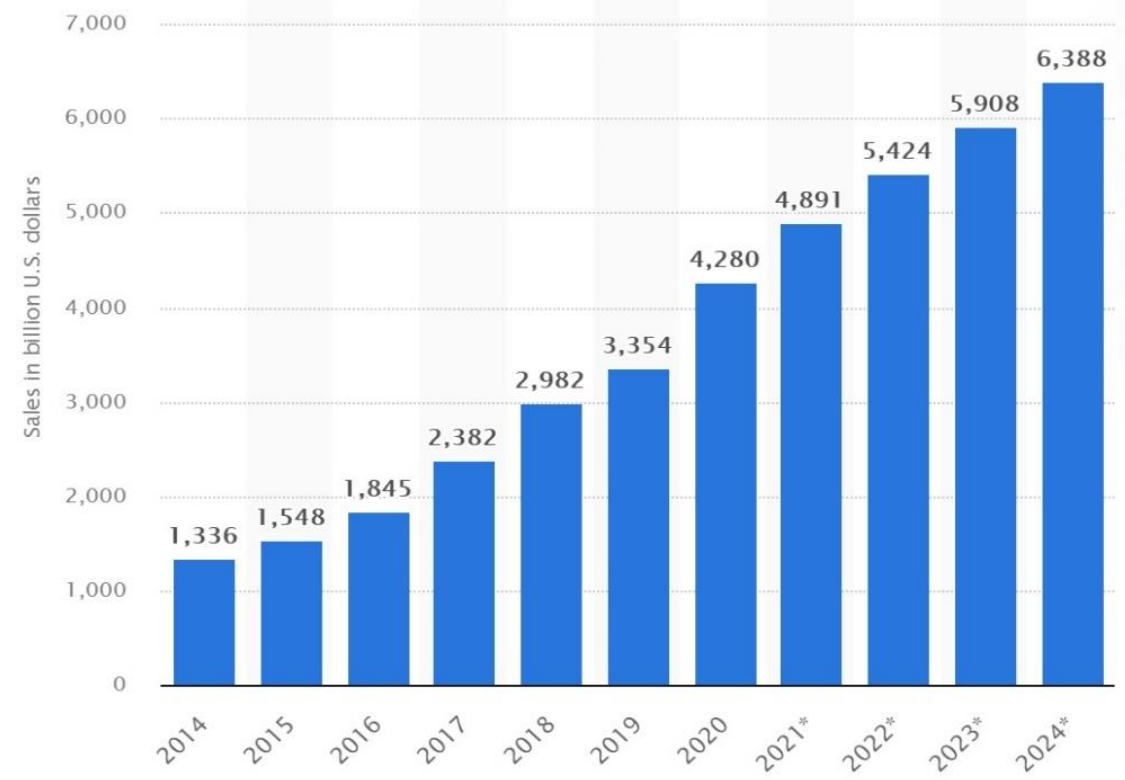

Source: Statista.com

With the integration of new services within the point of sale, the store staff is required to develop a new set of knowledge or a higher level than those already owned in order to make the shopping experience better and more enjoyable for customers.

$\square$ An example of this is the Elena Mirò brand and its new service called "Shopping Smart Box" (Zanin, 2020) with which a member of the store staff chooses some items to send to the customer who requested them, then keeping only those that are of interest. So, store staff must be able to understand customers' tastes and advise them on the solutions they believe will be most successful, a skill that was already important before, but which now plays an even more fundamental role.

The evolution of e-commerce will bring to an increasingly important role of marketplaces, that are the digital equivalent of department stores. Marketplaces are standing out for their ability to attract users and offer services that many brands alone would not be able to support, most of which are logistics-related services. Currently, $50 \%$ of e-commerce revenue from the sale of products is generated through marketplaces. Food, design, home furnishings, and fashion are the most active sectors on these platforms, with the use not only of generalist online stores but also niche marketplaces that, especially in the world of luxury and fashion, are having great success. 
A second key trend concerns the supply chains. For decades, the core features of supply chain management were globalization, low-cost supply, and minimal inventory. To increase the quality of consumer services, supply chains will have to be reorganized giving priority to their soundness but at the same time they will have to be more agile and flexible throughout the entire value chain. This will require further development in the efficiency of vertical relationships, also supported by increased data analytics capabilities. To shorten the time of all processes, some brands may have to move production or sources of products, in order to get closer to their target markets and this, in addition to advances in technologies (Internet of Things and 3D printing), may lead to a downsizing of the global division of labor as it has been experienced until now. In any case, logistics will play a key role in this case and the players who will make the largest investments in this field will be able to gain a decisive competitive advantage.

The third area of change relates to the consumer purchasing processes, on which further technological developments will exert a strong influence. Augmented reality will continue to develop further through the integration of localization and display devices directly into optical devices, as in the case of smart glasses (Ro et al., 2018), and more advanced solutions are already being tested through the plant of interface devices directly connected to human nerve terminals (Kim et al., 2020), with the perspective of creating connection systems capable of interacting directly with the cerebral perception system of people.

With the use of augmented reality, customers will be able to better understand their needs and if the products that they intend to purchase meet their demands. Both online and offline retailers have already started to experiment with augmented reality. Companies are using it not only to enhance the customer experience but also to allow shoppers the ability to test and explore products in the way that they would do during an in-person shopping experience.

This will amplify the potential of omnichanneling in the direction of metachanneling that will be more pervasive and able to further integrate the online and offline interaction.

At the same time, however, the demand for offline products and services will be oriented towards an emphasis on proximity, personalization and consumer active involvement, leading to the strengthening of those retail formats that can combine offer differentiation, atmospheres, entertainment, food tasting and social interaction. Independent operators will be able to exploit interstitial spaces complementary to leading brands (both of producers and retailers), but the largest part of the market will be in the hands of big players, who will be able to better exploit data analytics and artificial intelligence to profile consumers and anticipate their needs.

\section{Concluding Remarks}

The Covid19 emergency has shifted the focus of retail marketing strategies from the physical dimension of sales to the digital one. Some processes already underway have accelerated, while others, previously inconceivable, have become part of everyday life.

The pandemic crisis has accentuated the digital transformation of retail by accelerating the development of advanced omnichannel solutions. 
Academic studies on post Covid19 in retail have highlighted three main drivers: changes in consumer behavior; the redefinition of retail marketing strategies and sales spaces; the importance of adapting the supply chain.

The pandemic has changed consumer behavior, forcing retailers to adapt to a new normal, characterized by digitalization and flexibility.

With the redefinition of the role of physical stores and related spaces, a downsizing of store networks has occurred. The process - which was already underway before the pandemic - has now heavily accelerated.

Omnichannel strategy also requires, an upgrade of supply chains which can be difficult and costly to implement. Organizations must undertake broader and deeper transformations to meet growing consumer expectations in terms of consumer experience, personalization and delivery speed, while keeping delivery costs in check (Graf et al., 2021).

The challenge is epochal and seems to foster a further affirmation of the dominance of the largest retailers. The smaller retail operators seem to have little chance of success. However, some possible alternatives for small and medium retailers may still be valid. In particular, the development of partnerships with the largest retailers can make small entities as local reference for a renewed information and logistics function of the points of sale for consumers of this new digital era.

\section{Bibliography}

Abdelhadi, A. (2021). Applying Lean Manufacturing to Retail Business to Prevent the Spread of Covid 19. Academy of Strategic Management Journal, 20 (Special Issue 2), 1-5.

Accenture (2020). How is COVID-19 changing the retail consumer? Available at:

https://www.accenture.com/_acnmedia/PDF-130/Accenture-Retail-Research-POV-WaveSeven.pdf\#zoom=40 (Access date: $29 / 08 / 2020)$.

Alikhani, R., Torabi, S.A., \& Altay, N. (2021). Retail Supply Chain Network Design with Concurrent Resilience Capabilities. International Journal of Production Economics, 234. Art. No. 108042.

https://dx.doi.org/10.1016/j.ijpe.2021.108042

Bacile, T. J., Ye, C., \& Swilley, E. (2014). From Firm-Controlled to Consumer- Contributed: Consumer Co-Production of Personal Media Marketing Communication. Journal of Interactive Marketing, 28(2014), 117-133.

https://dx.doi.org/10.1016/j.intmar.2013.12.001

Barile, S., Polese, F., \& Sarno, D. (2018). Grocery Retailing in the I4.0 Era. Symphonya. Emerging Issues in Management (symphonya.unimib.it), (1), 38-51.

http://dx.doi.org/10.4468/2018.2.4barile.polese.sarno

Beckers, J., Weekx, S., Beutels, P., \& Verhetsel, A. (2021). COVID-19 and Retail: The Catalyst for E-commerce in Belgium? Journal of Retailing and Consumer Services, 62, Art. No. 10C645.

https://dx.doi.org/10.1016/j.jretconser.2021.102645

Bretas, V. P. G., \& Alon, I. (2020). The Impact of COVID-19 on Franchising in Emerging Markets: An Example from Brazil. Global Business and Organizational Excellence, 39(6), 6-16.

https://dx.doi.org/10.1002/joe.22053

Brondoni, S. M., \& Boccardelli, P. (2019). Ouverture de 'IR 4.0, Network Economies \& Stakeholder Engagement'. Symphonya. Emerging Issues in Management (symphonya.unicusano.it), (2), 1-7.

http://dx.doi.org/10.4468/2019.2.01ouverture 
Brondoni, S. M., \& Musso, F. (2010). Ouverture de 'Marketing Channels and Global Markets'. Symphonya. Emerging Issues in Management (symphonya.unimib.it), (1), 1-6.

http://dx.doi.org/10.4468/2010.1.01ouverture

Brondoni, S. M., \& Riboldazzi, S. (2015). Ouverture de 'Development Policies in Large Retailers'. Symphonya. Emerging Issues in Management (symphonya.unimib.it), (Special Issue), 1-7.

http://dx.doi.org/10.4468/2015.5.01ouverture

Brynjolfsson, E., Hu, Y. J., \& Rahman, M. S. (2013). Competing in the Age of Omnichannel Retailing. MIT Sloan Management Review, May.

Burgos, D., Ivanov, D. (2021). Food Retail Supply Chain Resilience and the COVID-19 Pandemic: A Digital Twin-Based Impact Analysis and Improvement Directions. Transportation Research Part E: Logistics and Transportation Review, 152, 102412.

https://dx.doi.org/10.1016/j.tre.2021.102412.

Chathoth, P., Altinay, L., Harrington, R. J., Okumus, F., \& Chan, E. S. (2013). Co-production versus Co-creation: A Process Based Continuum in the Hotel Service Context. International Journal of Hospitality Management, 32, 11-20.

https://dx.doi.org/10.1016/j.ijhm.2012.03.009

Chatterjee, S., Chaudhuri, R., \& Vrontis, D. (2021). Examining the Global Retail Apocalypse during the COVID-19 Pandemic Using Strategic Omnichannel Management: A Consumers' Data Privacy and Data Security Perspective. Journal of Strategic Marketing, 29(7), 617-632.

https://dx.doi.org/10.1080/0965254X.2021.1936132.

Civera, C., \& Freeman, R. E. (2019). Stakeholder Relationships and Responsibilities: A New Perspective. Symphonya. Emerging Issues in Management (symphonya.unicusano.it), (1), 40-58.

http://dx.doi.org/10.4468/2019.1.04civera.freeman

Cole, R., \& Shirgholami, Z. (2021). The Outlook for Modern Slavery in the Apparel Sector in a PostLockdown Economy. Supply Chain Management.

https://dx.doi.org/10.1108/SCM-06-2020-0245.

Demirkan, H., \& Spohrer, J. (2014). Developing a Framework to Improve Virtual Shopping in Digital Malls with Intelligent Self-Service Systems. Journal of Retailing and Consumer Services, 21, 860868.

https://dx.doi.org/10.1016/j.jretconser.2014.02.012.

Dmitry, N. (2013). Network Proximity on Practice: Context-aware Applications and Wi-Fi Proximity. International Journal of Open Information Technologies, 1(3), 1-4.

Dombey, D. (2021). Inditex and the Future of Retail: 'Don't Believe in the Death of the High Street'. Financial Times Online, $18^{\text {th }}$ July. Accessed September 13, 2021.

Druică, E., Musso, F., \& Ianole-Călin, R. (2020). Optimism Bias during the Covid-19 Pandemic: Empirical Evidence from Romania and Italy. Games, (11)3, 39-54.

http://dx.doi.org/10.3390/g11030039

Farrelly, G. (2012). The Role of Location Based Services in Shaping Sense of Place. ASIST 2012, October 28-31, Baltimore, MD, USA.

Fihartini, Y., Helmi, A., Hassan, M., \& Oesman, Y. M. (2021). Perceived Health Risk, Online Retail Ethics, and Consumer Behavior within Online Shopping during the COVID-19 Pandemic. Innovative Marketing, 17(3), 17-29.

https://dx.doi.org/doi:10.21511/im.17(3).2021.02

Filimonau, V., Vi, L. H., Beer, S., \& Ermolaev, V. A. (2021). The Covid-19 Pandemic and Food Consumption at Home and Away: An Exploratory Study of English Households. Socio-Economic Planning Sciences, Art. No. 101125.

https://dx.doi.org/10.1016/j.seps.2021.101125

Fornari, E., Grandi, S., \& Fornari D. (2018). Retailing 4.0: The New Era of E-commerce in Fast Moving Consumer Goods. Symphonya. Emerging Issues in Management (symphonya.unimib.it), (1), 40-58.

http://dx.doi.org/10.4468/2018.2.07fornari.grandi.fornari 
Fortuna, F., \& Risso M. (2019). Blockchain Technology in the Food Industry, Symphonya. Emerging Issues in Management (symphonya.unicusano.it), (2), 151-158.

http://dx.doi.org/10.4468/2019.2.13fortuna.risso

Freeman, R. E., \& Dmytriyev, S. (2019). Corporate Social Responsibility and Stakeholder Theory: Learning From Each Other. Symphonya. Emerging Issues in Management (symphonya.unicusano.it), (1), 7-15.

http://dx.doi.org/10.4468/2017.1.02freeman.dmytriyev.

Graf, C., Lange, T., Seyfert, A., \& van der Wijden, N. (2021). Into the Fast Lane: How to Master the Omnichannel Supply Chain. McKinsey \& Company. Available at:

https://www.mckinsey.com/industries/retail/our-insights/into-the-fast-lane-how-to-master-theomnichannel-supply-chain

Grewal, D., Gauri, D. K., Roggeveen, A.L., \& Sethuraman, R. (2021). Strategizing Retailing in the New Technology Era. Journal of Retailing, 97(1), 6-12.

https://dx.doi.org/10.1016/j.jretai.2021.02.004

Guthrie, C., Fosso-Wamba, S., \& Arnaud, J. B. (2021). Online Consumer Resilience During a Pandemic: An Exploratory Study of E-Commerce Behavior before, during and after a COVID-19 lockdown. Journal of Retailing and Consumer Services, 61, 102570.

https://dx.doi.org/10.1016/j.jretconser.2021.102570

Hall, M. C., Prayag, G., Fieger, P., \& Dyason, D. (2021). Beyond Panic Buying: Consumption Displacement and COVID-19. Journal of Service Management, 32(1), 113-128.

https://dx.doi.org/10.1108/JOSM-05-2020-0151

He, B., Mirchandani, P., Shen, Q., \& Yang, G. (2021). How should Local Brick-and-Mortar Retailers Offer Delivery Service in a Pandemic World? Self-building Vs. O2O Platform. Transportation Research Part E: Logistics and Transportation Review, 154, 102457.

https://dx.doi.org/10.1016/j.tre.2021.102457

Itani, O. S., \& Hollebeek, L. D. (2021). Consumers' Health-Locus-of-Control and Social Distancing in Pandemic-Based E-Tailing Services. Journal of Services Marketing, 19.

https://dx.doi.org/10.1108/JSM-10-2020-0410.

Ives, C.A., Cossick, B. \& Adams, D. (2019). Amazon Go: Disrupting Retail? Journal of Information Technology Teaching Cases, 9(1), 2-12.

https://dx.doi.org/10.1177/2043886918819092.

Jafarzadeh, H., Tafti, M., Ntezari, A., \& Sohrabi, B. (2021). All's well that Ends well: Effective Recovery from Failures during the Delivery Phase of E-Retailing Process. Journal of Retailing and Consumer Services, 62, 10260.

https://dx.doi.org/10.1016/j.jretconser.2021.102602

Jiang, Y., \& Stylos, N. (2021). Triggers of Consumers' Enhanced Digital Engagement and the Role of Digital Technologies in Transforming the Retail Ecosystem During COVID-19 Pandemic. Technological Forecasting and Social Change, 172, 121029.

https://dx.doi.org/10.1016/j.techfore.2021.121029

John, R., \& Dani, A. (2021). Influence of Mall Shopping Culture on Online Shopping Preferences: An Emerging Economy Perspective using the Technology Acceptance Model, Transnational Marketing Journal, 9(1), 17-32.

https://dx.doi.org/10.33182/tmj.v9i1.1241

Kazancoglu, I., \& Demir, B. (2021). Analysing Flow Experience on Repurchase Intention in ERetailing during COVID-19, International Journal of Retail and Distribution Management, 49(11), 1571-1593.

https://dx.doi.org/10.1108/IJRDM-10-2020-0429

Khaled, A. S. D., Alabsy, N. M., Al-Homaidi, E. A., \& Saeed, A. M. M. (2020). The Impact of the COVID-19 Pandemic on Retailer Performance: Empirical Evidence from India. Innovative Marketing, 16(4), 129-138.

http://dx.doi.org/10.21511/im.16(4).2020.11 
Kim, H., Kwon, Y. T., Lim, H. R., Kim, J. H., Kim, Y. S., \& Yeo, W. H. (2020). Recent Advances in Wearable Sensors and Integrated Functional Devices for Virtual and Augmented Reality Applications. Advanced Functional Materials, 31(2005692), 1-12.

http://dx.doi.org/10.1002/adfm.202005692

Lavuri, R. (2021). Intrinsic Factors Affecting Online Impulsive Shopping During the COVID-19 in Emerging Markets. International Journal of Emerging Markets.

https://dx.doi.org/10.1108/IJOEM-12-2020-1530

Levesque, N., \& Boeck, H. (2017). Proximity Marketing as an Enabler of Mass Customization and Personalization in a Customer Service Experience, in Bellemare, J., Carrier, S., Nielsen, K., \& Piller, F. (eds) Managing Complexity (405-420). Springer Proceedings in Business and Economics. Springer, Cham.

https://dx.doi.org/10.1007/978-3-319-29058-4_32

Love, E., Ehrlich, S., \& Sullins, M. (2021). Colorado Producers during COVID-19: A Closer Look at the Potato Supply Chain. Journal of Food Distribution Research, 52(1), 102-103.

Luce, L. (2019). Computer Vision and Smart Mirrors, in Artificial Intelligence for Fashion (39-51). https://dx.doi.org/10.1007/978-1-4842-3931-5_3

Masudin, I., Ramadhani, A., Restuputri, D.P., \& Amallynda, I. (2021). The Effect of Traceability System and Managerial Initiative on Indonesian Food Cold Chain Performance: A Covid-19 Pandemic Perspective. Global Journal of Flexible Systems Management, 22(4), 331-356.

https://dx.doi.org/10.1007/s40171-021-00281-x

McCormick, H., Cartwright, J., Perry, P., Barnes, L., Lynch, S., \& Ball, G. (2014). Fashion RetailingPast, Present and Future. Textile Progress, 46(3), 227-321.

https://dx.doi.org/10.1080/00405167.2014.973247

Mefi, N. P., \& Asoba, S. N. (2020). Employee Motivation in Crisis Situations: The Case of a Selected Organization in the Food and Retail Sector in Cape Town. Academy of Entrepreneurship Journal, 2782), 1-8.

Milman, A., Tasci, A.D.A., \& Wei, W. (2020). Crowded and Popular: The Two Sides of the Coin Affecting Theme-Park Experience, Satisfaction, and Loyalty. Journal of Destination Marketing and Management, 18, 100468.

https://dx.doi.org/10.1016/j.jdmm.2020.100468

Mofokeng, T .E. (2021). The Impact of Online Shopping Attributes on Customer Satisfaction and Loyalty: Moderating Effects of E-Commerce Experience. Cogent Business and Management, 8(1), 1968206.

https://dx.doi.org/10.1080/23311975.2021.1968206.

Montoya, C. J. R., \& Flores, J. L. M. (2021). Contingency Plan in the Supply Chain of Companies in the Retail Industry in the Face of the Impacts of COVID-19. Advances in Science, Technology and Engineering Systems, 6(1), 819-832.

https://dx.doi.org/10.25046/aj060191

Moses, E., \& Clark, K. R. (2020). The Neuromarketing Revolution: Bringing Science and Technology to Marketing Insight, in Chkoniya, V., Madsen, A., \& Bukhrashvili, P. (eds.), Anthropological Approaches to Understanding Consumption Patterns and Consumer Behavior (449-464). IGI Global. http://dx.doi:10.4018/978-1-7998-3115-0.ch024

Musso F. (2010). Innovation in Marketing Channels. Symphonya. Emerging Issues in Management (symphonya.unimib.it), (1), 23-42.

http://dx.doi.org/10.4468/2010.1.04musso

Musso, F., \& Adam, R. (2020). Retailing 4.0 and Technology-Driven Innovation: A Literature Review, in Musso, F. \& Druica, E. (eds.), Handbook of Research on Retailing Techniques for Optimal Consumer Engagement and Experiences, 338-354. Hershey, PA: IGI Global.

http://dx.doi.org/10.4018/978-1-7998-1412-2.ch015 
Namiot, D., \& Sneps-Sneppe, M. (2013). Social Streams Based on Network Proximity. International Journal of Space-Based and Situated Computing, 3(4), 234-242.

https://dx.doi.org/10.1504/IJSSC.2013.058375

Ngo, L. V., \& O’cass, A. (2013). Innovation and Business Success: The Mediating Role of Customer Participation. Journal of Business Research, 66(2013), 1134-1142.

https://dx.doi.org/10.1016/j.jbusres.2012.03.009

Northington, W. M., Gillison, S. T., Beatty, S. E., \& Vivek, S. (2021). I Don't Want to Be a Rule Enforcer During the COVID-19 Pandemic: Frontline Employees' Plight. Journal of Retailing and Consumer Services, 63, 102723.

https://dx.doi.org/10.1016/j.jretconser.2021.102723

OECD (2020). Digital Transformation in the Age of COVID-19: Building Resilience and Bridging Divides. Digital Economy Outlook 2020 Supplement, OECD, Paris.

www.oecd.org/digital/digital-economy-outlook-covid.pdf

Oh, L., Teo, H., \& Sambamurthy, V. (2012). The Effects of Retail Channel Integration Through the Use of Information Technologies on Firm Performance. Journal of Operations Management, 30(5), 368-381.

https://dx.doi.org/10.1016/j.jom.2012.03.001

Olsson, T., Lagerstam, E., \& Kärkkäinen, T. (2011). Expected User Experience of Mobile Augmented Reality Services: A User Study in the Context of Shopping Centers. Personal and Ubiquitous Computing, Febraury. https://dx.doi.org/10.1007/s00779-011-0494-X

Omar, N. A., Nazri, M. A., Ali, M. H., \& Alam, S. S. (2021). The Panic Buying Behavior of Consumers during the Covid-19 Pandemic: Examining the Influences of Uncertainty, Perceptions of Severity, Perceptions of Scarcity, and Anxiety. Journal of Retailing and Consumer Services, 62, (102600).

https://dx.doi.org/10.1016/j.jretconser.2021.102600

Pantano, E., Pizzi, G., Scarpi, D., \& Dennis, C. (2020). Competing during a Pandemic? Retailers' Ups and Downs During the COVID-19 Outbreak. Journal of Business Research, 116, 209-213.

https://dx.doi.org/10.1016/j.jbusres.2020.05.036

Pantano, E., Priporas, C. V., \& Dennis, C., 2018. A New Approach to Retailing for Successful Competition in the New Smart Scenario. International Journal of Retail \& Distribution Management, 46(3), 264-282.

https://dx.doi.org/10.1108/IJRDM-04-2017-0080.

Park, A., An, H. S., Song, J. M., \& Chung, C. (2021). Please do not Disturb: the Effect of Zero-Contact Marketing on Korean Consumers' Decision-Making Process. Asia Pacific Journal of Marketing and Logistics.

https://dx.doi.org/10.1108/APJML-09-2020-0641

Polacco, A., \& Backes, K. (2018). The Amazon Go Concept: Implications, Applications, and Sustainability. Journal of Business and Management, 24(1), 79-92.

https://dx.doi.org/10.6347/JBM.201803_24(1).0004

Pradhan, S., Bhatkal, S. (2021). DMart: Driving Growth in a Changed Business Environment. Emerald Emerging Markets Case Studies, 11(3), 1-31.

https://doi.org/10.1108/EEMCS-10-2020-0371

Pratiwi, A. A., Maftuhah, D. I., Wessiani, N. A., Partiwi, S. G., \& Gunarta, I. K. (2021). A Causality Analysis Framework for Analyzing the Retail Consumer Behavior Change in COVID-19 Pandemic. Proceedings of the International Conference on Industrial Engineering and Operations Management, 2426-2436.

Premnath, D. (2021). Applications of Neuromarketing Sciences on Digital Marketing Models-A Theoretical Frame Work. Turkish Journal of Computer and Mathematics Education, 12(7), 31273132.

https://dx.doi.org/10.17762/turcomat.v12i7.3929 
Riboldazzi, S. (2016). Global Markets and Development Policies in Large-Scale Retailers. Symphonya. Emerging Issues in Management (symphonya.unimib.it) (Special Issue on Development Policies in Large Retailers), 8-28.

http://dx.doi.org/10.4468/2015.5.02riboldazzi.

Ro, Y. K., Brem, A., \& Rauschnabel, P. A. (2018). Augmented Reality Smart Glasses: Definition, Concepts and Impact on Firm Value Creation, in Ro, Y. K., Brem, A., \& Rauschnabe, P. A. (eds), Augmented reality and virtual reality, 169-181. Springer, Cham.

Rosenbloom, B. (2007). Multi-channel Strategy in Business-to-Business Markets: Prospects and Problems. Industrial Marketing Management, 36, 4-9.

https://dx.doi.org/10.1016/j.indmarman.2006.06.010

Sathyanarayana, A., Shukla, N., \& Taghikhah, F. (2020). Modelling the Impact of COVID-19 Pandemic on a Hardware Retail Supply Chain. IEEE International Conference on Industrial Engineering and Engineering Management, 2020-December, Art. No. 9309973, 807-811.

https://dx.doi.org/10.1109/IEEM45057.2020.9309973

Schleper, M. C., Gold, S., Trautrims, A., \& Baldock, D. (2021). Pandemic-induced Knowledge Gaps in Operations and Supply Chain Management: COVID-19's Impacts on Retailing. International Journal of Operations and Production Management, 413(3), 193-205.

https://dx.doi.org/10.1108/IJOPM-12-2020-0837

Schoeman, A., Bick, G., \& Barnardo, C. (2021). Cape Union Mart: Digital Transformation and Customer Experience During a Crisis. Emerald Emerging Markets Case Studies, 11(3), 1-47.

https://dx.doi.org/10.1108/EEMCS-04-2021-0116

Shankar, V., Kalyanam, K., Setia, P., Golmohammadi, A., Tirunillai, S., Douglass, T., Hennessey, J., Bull, J. S., \& Waddoups, R. (2021). How Technology is Changing Retail. Journal of Retailing, 97(1), 13-27.

https://dx.doi.org/10.1016/j.jretai.2020.10.006

Sharma, M., Luthra, S., Joshi, S., \& Kumar, A. (2021). Accelerating Retail Supply Chain Performance against Pandemic Disruption: Adopting Resilient Strategies to Mitigate the Long-Term Effects, Journal of Enterprise Information Management,

https://dx.doi.org/10.1108/JEIM-07-2020-0286

Sheth, J. N. (2021). Future of Brick and Mortar Retailing: How Will It Survive and Thrive? Journal of Strategic Marketing, 29(7), 598-607.

https://dx.doi.org/10.1080/0965254X.2021.1891128

Showrav, D. G. Y., Hassan, M. A., Anam, S., \& Chakrabarty, A. K. (2021). Factors Influencing the Rapid Growth of on In-Shopping during Covid-19 Pandemic Time in Dhaka City, Bangladesh. Academy of Strategic Management Journal, 20 (Special Issue 2), 1-13.

Siriwardhana, Y., De Alwis, C., Gur, G., Ylianttila, M., \& Liyanage, M. (2020). The Fight against the COVID-19 Pandemic with SG Technologies. IEEE Engineering Management Review, 48(3), Art. No. 9170773, 72-84.

Smith, A. (2020). Increasing In-Store Sales through Creative Omni-Channel Digital and Social Media Marketing Strategies: Case Study of Hobby Town. Journal of Digital and Social Media Marketing, $8(3), 202-212$.

Tanveer, M., Hassan, S. \& Bhaumik, A. (2020). COVID-19 Quarantine and Consumer Behavior that Change the Trends of Business Sustainability and Development. Academy of Strategic Management Journal, 19(4), 1-11.

Thaipradit, K., \& Tantong, P. (2021). The Influence of Relationship Marketing on the Loyalty of Generation Y and Generation Z Customers for Online Retail Businesses during the Covid-19 Crisis. Academy of Strategic Management Journal, 20 (Special Issue 5), 1-10.

Untaru, E. N., \& Han, H. (2021). Protective Measures against COVID-19 and the Business Strategies of the Retail Enterprises: Differences in Gender, Age, Education, and Income among Shoppers. Journal of Retailing and Consumer Services, 60, 102446.

https://dx.doi.org/10.1016/j.jretconser.2021.102446 
Wang, Y., Xu, R., Schwartz, M., Ghosh, D., \& Chen, X. (2020). COVID-19 and Retail Grocery Management: Insights from a Broad-Based Consumer Survey. IEEE Engineering Management Review, 48(3), 202-211.

https://dx.doi.org/10.1109/EMR.2020.3011054

Willems, K., Brengman, M., \& Van De Sanden, S. (2017). In-store Proximity Marketing: Experimenting with Digital Point-of-Sales Communication. International Journal of Retail \& Distribution Management, 45(7/8), 910-927.

https://dx.doi.org/10.1108/IJRDM-10-2016-0177

Yang, M., Han, C., Cui, Y., \& Zhao, Y. (2021). COVID-19 and Mobility in Tourism Cities: A Statistical Change-Point Detection Approach. Journal of Hospitality and Tourism Management, 47, 256-261.

https://dx.doi.org/10.1016/j.jhtm.2021.03.014

Zhang, L., Wu, L., Huang, L., \& Zhang, Y. (2021). Wield the Power of Omni-channel Retailing Strategy: a Capability and Supply Chain Resilience Perspective. Journal of Strategic Marketing.

https://dx.doi.org/10.1080/0965254X.2021.1972440 